\title{
ESTABLISHMENT OF THE BONE TISSUE BANK AT MOSTAR UNIVERSITY CLINICAL HOSPITAL
}

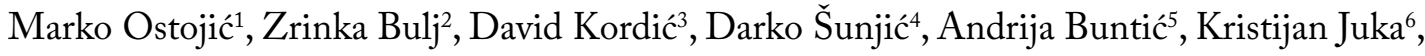

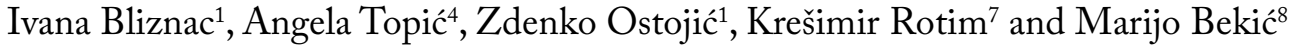 \\ ${ }^{1}$ Department of Orthopedics, Mostar University Clinical Hospital, Mostar, Bosnia and Herzegovina; \\ ${ }^{2}$ Department of Orthopedics, University of Bologna, Bologna, Italy; \\ ${ }^{3}$ Emergency Department, Mostar Public Health Centre, Mostar, Bosnia and Herzegovina; \\ ${ }^{4}$ Faculty of Electrical Engineering, Mechanical Engineering and Computer Science, \\ University of Mostar, Mostar, Bosnia and Herzegovina; \\ ${ }^{5}$ Department of Histology and Embryology, University of Mostar, Mostar, Bosnia and Herzegovina; \\ ${ }^{6}$ Department of Surgery, Mostar University Clinical Hospital, Mostar, Bosnia and Herzegovina; \\ ${ }^{7}$ Department of Neurosurgery, Sestre milosrdnice University Hospital Centre, Zagreb, Croatia; \\ ${ }^{8}$ Dubrovnik General Hospital, Dubrovnik, Croatia
}

\begin{abstract}
SUMMARY - Bone tissue banks are necessary for collection, production, testing, packaging, storage and delivery of bone transplants. Bone tissue bank is a link between the donor and the recipient by which the donation becomes a medium of health improvement for both the donor and the recipient. At the Department of Orthopedics, Mostar University Clinical Hospital, about 200 total hip replacements are performed per year. Most patients undergoing total hip replacement surgery (90\%) have been diagnosed with osteoarthritis, and they are suitable donors, having in mind their age and comorbidities. In the same Department, around 50 procedures that require bone transplants are performed per year. A team of highly competent surgeons are working on an intensive process of adaptation oriented to quality improvement and intensification of the activity, both with the goal of meeting the standards of excellence in orthopedic surgery. The presence of a bone tissue bank has a favorable impact on the quality of health care owing to bone transplant availability, as well as on the scientific role of a highly specialized institution that examines the properties of bone tissue.
\end{abstract}

Key words: Tissue banks; Bone banks; Arthroplasty, replacement, hip; Bone transplantation

\section{Introduction}

Bone tissue banks are necessary for collection, production, testing, packaging, storage and delivery of bone grafts. According to legal and quality demands, their main objective is to preserve biological characteristics and assure microbiological safety of the graft $^{1}$. First human bone transplantation was performed be-

Correspondence to: Assist. Prof. Marko Ostojic, $M D, P h D$, Department of Orthopedics, Mostar University Clinical Hospital, Bijeli brijeg bb, Mostar 88 000, Bosnia and Herzegovina

E-mail: marko.ostojic@ymail.com

Received May 31, 2019, accepted August 27, 2019 fore one hundred and twenty years ${ }^{2}$. Bone tissue bank is a link between the donor and the recipient by which the donation becomes a medium of health improvement for both the donor and the recipient. Establishment of bone tissue bank cannot be separated from optimization of a safe and efficient system for tissue storage, which would represent the main pillar in founding the primary activity of a tissue bank. The need for transplantation of a bone mass or other bone grafts has increased, especially regarding complex procedures which include large tissue defect ${ }^{3-4}$. The everincreasing need for musculoskeletal tissue for transplantation is the consequence of the evolution of sur- 
gical technique, which requires that many different clinical services be ready to obtain their own source of grafts 5 .

There are different techniques for storage and preservation, e.g., dry freezing, demineralization, radiation, etc. The most commonly used are the technique of deep freeze and lyophilization (freezing via drying out the tissue) $)^{6}$.

The concept of a tissue bank became a reality during and after World War II, when the National Naval Tissue Bank was formed in Bethesda, and a series of small banks arose all over the world ${ }^{1}$. Following European standards and guidelines for quality, the means of collection, storage and analysis of bone tissue, the first steps towards systematic organization of the Bone Tissue Bank at the Department of Orthopedic Surgery, Mostar University Clinical Hospital were taken under professional supervision by Professor Zdenko Ostojić.

About 200 total hip replacements are performed annually at the Department of Orthopedics, Mostar University Clinical Hospital. Most of the patients (70\%-80\%) undergoing total hip replacement surgery are diagnosed with osteoarthritis and they are suitable donors, also having in mind their age and comorbidities. The bone of an osteoarthritis affected joint has a satisfactory quality and density of bone lamellae and can be used as a graft. The patients undergoing the same operation for other reasons (rheumatoid arthritis, posttraumatic arthritis, femoral neck fracture) do not satisfy the criteria for donorship. It should also be kept in mind that donors should be younger patients. We believe that approximately $40 \%$ of patients are suitable donors, i.e. have good bone quality. There are around 50 different operations performed annually, which require bone grafts for reparation of tissue defect. These are resections of bone tumors, revision operations of endoprosthesis implantation, pseudoarthrosis operations and different traumas with bone defects that require bone graft. Currently, at the Ortho Clinic mostly autologous operations are performed at our Department of Orthopedic Surgery. Homologous transplantation is performed to a much lesser extent than desired. Femoral heads are being taken, but they are frozen at a $-18{ }^{\circ} \mathrm{C}$, which greatly reduces their expiration time. Essential microbiological analysis is fundamental regarding general surveillance of donor conditions, which is routinely performed. Upgrading the quality of bone bank functioning greatly contributes to better graft selection and utilization.

\section{Foundation of the Bone Tissue Bank}

Bone tissue is the most prevalent support tissue in the human body ${ }^{7}$. Storage of bone tissue is the first step in the formation of the Bone Tissue Bank and it provides long-term availability of the tissue and its continuous usage. The processes for improvement of bone treating procedures and technical advancements are lyophilization (dry freezing), demineralization, morcellation, segmentation, and manufacturing bone within cellulose hydrogel with growth factors. All these processes are used to make the adapted product as perfect as possible and to achieve personalized care for each patient. We believe that the formation of the Bone Tissue Bank warrants long-term savings to the local healthcare system. In the future, with further development of an oncologic center and their ability to provide high doses of radiation, the possibility of sterilizing grafts via radioactive cobalt is evident, but not yet available in our region. The formation of a modern bone tissue bank provides better and faster treatment of complex cases in reconstructive surgery of the locomotor system offering safe and adequate help in a short time. This will contribute to improvement of patient care, reduce hospital stay and need for hospitalization in general, which will certainly reflect in the economic aspect by saving cost and reducing the burden on the health care system. The full effect of the bone tissue bank can only be realized by multi-organ explantation during which other parts of the musculoskeletal system are also included. The presence of the bone tissue bank has become a reference point for scientific and clinical research, as well as for optimization of clinical protocols worldwide.

\section{Organization and Medical Staff}

With development of a good bone tissue bank, our team of scientists can completely fulfill all predispositions for tissue engineering of the locomotor system and has all the conditions for further research into mechanical characteristics of the bone, microscopic variations of bone lamellae and further integrations of bone grafts from the donor bone, either by radiologic methods or cadaver research. A team of highly competent surgeons has been working on adaptation oriented towards quality improvement and increasing activity with the goal of meeting the excellence standard of orthopedic surgery. 
With organ, tissue and cell transplantation as a fast-developing field of medicine which offers many opportunities for quality improvement in the treatment of until now hardly or not treatable diseases, it is a professional and scientific necessity of our institution to follow the European and world standard in the utilization of the possibilities and techniques available. The use of bone grafts or transplants is one of the most important procedures for filling out the bone defect, and sometimes even to improve the process of healing $^{8}$. Good functioning of a bone tissue bank is only possible with a high scientific level and technical equipment. Education of medical staff and preclinical scientific research at the school of medicine surely contributes to functioning of the mentioned facility. It is the goal of this project to realize interdisciplinary collaboration between the Mostar University Clinical Hospital, School of Medicine and Faculty of Electrical Engineering, Mechanical Engineering and Computer Science, University of Mostar, whose scientific staff would be in charge of testing biomechanical properties of the bone. It is of paramount importance to keep high standard of the bone tissue bank for both scientific improvement and safety. Good organization of the bone tissue bank and upgrading it to a higher level will allow for better and more systematic collection, preparation and storage of the bone. In that way, we will have bone grafts available before the operation, which enables better planning. The existence of such a bone tissue bank will influence the quality of health care through faster graft availability and highly specialized scientific facility focused on the properties of bone tissue. It is possible to cover the increasing need for bone and joint tissue with homologous (allogeneic) donation.

\section{Procedure}

In the beginning, the material for the bone tissue bank is obtained during hip replacement surgery (the head of the femur), whereas later on, along with advancement of transplant surgery, our Department will be able to participate in multi-organ explantations according to legal requirements in our country. Patients undergoing hip replacement surgery for degenerative disease may donate the head of the femur, which has to be completely removed to allow implantation of the prosthesis, thus making medical waste useful ${ }^{9}$. The head of the femur can be used as a massive bone graft of 4 to $5 \mathrm{~cm}$ in diameter, or it can be ground into pieces of spongious bone of $3 \mathrm{~mm}$ in diameter (morcellation). Microbiological samples are obtained from the graft. A piece of the bone is also obtained for testing of biophysical properties, and an even smaller sample for histologic analysis of bone lamellae. The standard procedure which involves deep freeze may change mechanical properties of the graft ${ }^{10}$. After thorough explanation using a consent form, the living donor approves donation of the head of the femur for storage by signature. A detailed informed consent was translated from the Rizzoli Clinic of Bologna, which has a modern bone tissue bank, one of the best in Europe. The biggest complication that needs to be avoided is transmission of a virus or bacterium borne disease ${ }^{11}$ from the donor to the recipient by either an organism present at the donor site or by contamination ${ }^{12}$.

The donor also undergoes extended blood testing for different infectious diseases, which may greatly help detect a potential disease he has not been aware of before. Data are collected in a patient form. Physicians authorized for bone explantation, a nurse in charge of the bone tissue bank and leader of the bone tissue bank are the ones participating in this project. As per authorization, the physicians will assess general wellbeing of the donor based on the initial clinical examination and serology test results. If the patient is deemed a suitable potential donor, the process of data collection and analysis via detailed history and filling out the respective forms may commence. It is preferable to have a physician present to give information or to answer possible dilemmas. Maximum privacy is advised, as well as having trust in the present physician. Based on thorough medical and social history, physical examination, clinical findings and laboratory workup, the person in charge collects information regarding medical history, social environment and sexual activity. Appropriate preliminary assessment saves time, resources and material. As per documentation, every step of the process regarding the bone tissue bank is strictly and irrevocably documented, and every bone graft contains a revision trace with donor and recipient confidentiality according to the highest standards ${ }^{13}$.

After it has been collected, the bone graft is labeled, packed and stored in a sterile, single use kit composed of 2 nylon bags and a plastic container. Shelf life of a graft collected that way and frozen at $-86^{\circ} \mathrm{C}$ is 5 years, after which time it will be eliminated by regulated process. 
The heads of the femurs used in the first phase of this project were easily applied for the following procedures: revision of hip replacements, filling out bone defects after tumor resections or less frequently trau$\mathrm{ma}$, treatment of pseudoarthrosis (here the technique of spongioplasty is more commonly used), filling out bone cysts, use of bone wedge for treating varus and valgus deformities, and a whole range of complicated cases concerning bone surgery.

\section{Microbiological Testing}

Patients not eligible for donation and patients with definitive exclusion criteria for transplantation are persons with clinical or laboratory active human immunodeficiency virus (HIV), hepatitis B virus (HBV), $\mathrm{HCV}$ infection or clinically evident jaundice, people with risk factors for HIV, HBV and HCV, persons exhibiting risky sexual behaviors in the last 12 months, persons who have used intravenous substances in the last 12 months, persons at hemophilia, persons diagnosed with sexually transmitted infection in the last 12 months, partners of people with high risk of HIV, $\mathrm{HBV}$ and $\mathrm{HCV}$ in the last 12 months, people suffering from systemic infections that are poorly regulated in the envisioned time of donation including bacterial, viral, mycotic and parasitic infections, people with dementia or chronic degenerative disease of the central nervous system (multiple sclerosis, amyotrophic lateral sclerosis, Parkinson's disease), persons having undergone surgery or blood transfusion in Great Britain during the 1984-1996 period, Reye's syndrome, ongoing malignancy, patients having undergone transplantation, vaccination with live attenuated vaccines (measles-mumps-rubella (MPR), varicella, yellow fever, smallpox) 4 weeks before donation, people at risk of acquiring a travel related infectious disease or who have been exposed to infectious agents.

\section{Mechanical and Histologic Testing}

Bone grafts will be timely examined for evaluation of biomechanical properties and microscopic orientation and quality of the lamellae. Evaluation of mechanical stiffness and elasticity of the grafts will be done in cooperation with the scientists at the Faculty of Engineering, University of Mostar. From each femoral head, a $1 \times 2 \mathrm{~cm}$ bone sample will be obtained for mechanical evaluation and will be eliminated afterwards because of contamination. Mechanical engineers will test the hardness and toughness (i.e. brittleness) of the bone sample, and only those specimens with the best mechanical properties will be retained. Samples with the best hardness and elasticity will be stored, whereas those with unsatisfactory characteristics will be discarded. This mode of selection will eliminate additional $20 \%-30 \%$ of the grafts.

There are two measuring devices used for the abovementioned examinations. The universal testing machine is a device used for testing the tensile and compressive strength of the materials under uniaxial static loading conditions. Universal testing machine is an essential piece of equipment in every laboratory that does mechanical testing. Testing of the material brittleness is performed on a Charpy pendulum as a short-acting dynamic test. The aim is to determine the behavior of the material under shock load conditions. Tensile toughness is a measurement of toughness and resistance to brittle fracture. Toughness is the ability of a material to absorb energy and plastically deform, resisting fracturing. The examination of tensile toughness is performed at room temperature. Based on the difference of the potential energy of the mallet between the initial and final position, the energy spent to break the sample (tensile toughness) is calculated.

A sample for microscopic evaluation of quality and orientation of the lamellae will also be obtained from the bone. The orientation of the lamellae will define the direction for the in situ implementation of the graft, so that the direction of the lamellae is parallel with the line of the mechanical load.

The idea is to impregnate all of the grafts with gentamicin, an antibiotic that is used locally, for example, mixed with bone cement. A depot preparation with gradual release of the active substance would be used.

\section{Conclusion}

Our activities are planned according to the following:

- supporting organ donation as a conscious choice,

- giving support and training to medical staff,

- guaranteeing optimal use of a generous essay of donors,

- guaranteeing privacy of the donor and respect for human integrity, 
- ensuring highest standards of safety and quality of the tissue,

- making good foundation for scientific research into mechanical and histologic bone properties,

- ensuring conditions for future storage of multiorgan explantation,

- improving the quality of life of the donor through thorough serology testing and validating current general well-being, and

- existence of Bone Tissue Bank at the Mostar University Clinical Hospital will greatly improve the quality of medical care.

\section{References}

1. Hernigou P. Bone transplantation and tissue engineering. Part III: Allografts, bone grafting and bone banking in the twentieth century. Int Orthop. 2015 Mar;39(3):577-87. doi: 10.1007/s00264-015-2669-y.

2. Prus A, Kalus U. Bone banks: the state-of-the-art. Orthopade. 2018;47(1): 3-9. (in German) doi: 10.1007/s00132-017-3504-5.

3. Tomford WW. Bone allografts: past, present and future. Cell Tissue Bank. 2000;1(2):105-9.doi:10.1023/A:1010158731885.

4. Babiker H. Bone graft materials in fixation of orthopaedic implants in sheep. Dan Med J. 2013;60(7):B4680.
5. Šebečić B, Japjec M, Dojčinović B, Žgaljardić I, Starešinić M. Aggressive granulomatosis after cementless total hip arthroplasty as a result of inflammatory reaction to metal debris: case report. Acta Clin Croat. 2013;52(4):492-6.

6. Cimbalista de Alencar PG, Ventura Vieira IF. Bone banks. Rev Bras Ortop. 2010:45(6):524-8. doi: 10.1016/S2255-4971(15) 30297-4.

7. Legović D, Šantić V, Gulan G, et al. Osiguranje kvalitete i sigurnosti koštanih presadaka metodom smrzavanja. Med Flum. 2009;45(1):14-21. (in Croatian)

8. Đudarić L, Zoričić Cvek S, Cvijanović O, Fužinac-Smojver A, Ćelić T, Martinović D. Osnove biologije koštanog tkiva. Med Flum. 2014;50(1):21-38. (in Croatian)

9. Hovanyecz P, Lorenti A, Lucero JM, Gorla A, Castiglioni AE. Living donor bone banking: processing and discarding - from procurement to therapeutic use. Cell Tissue Bank. 2015; 16(4):593-603. doi: 10.1007/s10561-015-9507-8.

10. Chandoke RK, Kapoor SK. Effect of bone bank processing on bone mineral density, histomorphometry and biomechanical strength of retrieved femoral head. Indian J Med Res. 2017; 146(Suppl):S45-S50. doi: 10.4103/ijmr.IJMR_739_15.

11. Stepanovic ZL, Ristic BM. The effectiveness of bone banking in central Serbia: audit of the first seven years. Cell Tissue Bank. 2014;15(4):567. doi: 10.1007/s10561-014-9426-0.

12. Tomford WW. Transmission of disease through transplantation of musculoskeletal allografts. J Bone Joint Surg Am. 1995;77 (11):1742-54. doi: 10.2106/00004623-199511000-00017

13. Czitrom AA, Gross AE. Allografts in Orthopedic practice. Baltimore, USA: Williams \& Wilkins. 1992.

Sažetak

\title{
RAZVOJ BANKE KOŠTANOG TKIVA U SVEUČILIŠNOJ KLINIČKOJ BOLNICI MOSTAR
}

\author{
M. Ostojic, Z. Bulj, D. Kordic, D. Šunjic, A. Buntic, K. Juka, I. Bliznac, A. Topic, Z. Ostojic, K. Rotimi M. Bekic
}

Banke koštanog tkiva su odgovorne za skupljanje, proizvodnju, ispitivanje, pakiranje, skladištenje i isporuku koštanih transplantata. Banka koštanog tkiva premosnica je od donora $\mathrm{k}$ primatelju prilikom koje se donacija pretače u sredstvo za poboljšanje zdravstvenog stanja kako primatelja tako i davatelja. Na Klinici za ortopediju Sveučilišne kliničke bolnice Mostar na godinu se ugradi oko 200 totalnih proteza kuka. Većini bolesnika kojima se ugrađuje totalna proteza kuka (90\%) identificirana je dijagnoza osteoartritisa te su pogodni davatelji, s tim da se u obzir uzimaju komorbiditeti i životna dob. Na godinu se na Klinici izvodi oko 50 različitih operacija za koje trebaju koštani presatci. Tim visoko kompetentnih kirurga bavi se intenzivnim procesom adaptacije koji je orijentiran poboljšanju kvalitete i jačanju aktivnosti s ciljem zadovoljenja standarda izvrsnosti u ortopedskoj kirurgiji. Prisutnost ovakve koštane banke učinkovito utječe na kvalitetu skrbi kako zbog brže dostupnosti implantata tako i zbog znanstvene uloge visoko specificirane ustanove koja bazično istražuje svojstva koštanog tkiva.

Ključne riječi: Tkivo, banka; Kost, banka; Artroplastika zgloba kuka; Transplantacija kosti 